\title{
GAMBARAN POLA MAKAN DAN STRESS PADA PENDERITA GASTRITIS DI PUSKESMAS SIMPANG IV SIPIN KOTA JAMBI
}

\author{
Aura Maulia Mustika1 ${ }^{1}$ Dasuki $^{2}$, Nofrida Saswati ${ }^{3}$ \\ ${ }^{1}$ Mahasiswa Program Studi Ilmu Keperawatan STIKES Harapan Ibu \\ ${ }^{2,3}$ Dosen Program Studi IImu Keperawatan STIKES Harapan Ibu
}

Email : mauliaaura@gmail.com

\section{ABSTRACT : OVERVIEW OF DIET AND STRESS IN GASTRITIS PATIENTS AT SIMPANG IV SIPIN HEALTH CENTER, JAMBI CITY}

Introduction : Gastritis, known as ulcer disease, is a disease of the upper digestive tract that many people complain about. The number of cases of gastritis in various countries is quite high. Gastritis is one of the top ten diseases among hospitalized clients in Indonesia with a total of 30,154 cases. One of the factors that cause gastritis is diet and stress.

Purpose : This study aims to determine the description of diet and stress with gastritis at Simpang IV Sipin Public Health Center Jambi City in 2020.

Method : This research is a quantitative research with descriptive research methods. The population in this study were all gastritis clients who visited the Simpang IV Sipin Public Health Center in Jambi City in September 2020, amounting to 45 clients and sampling was carried out using total sampling techniques, amounting to 45 clients. The data was collected using a questionnaire sheet and the results of this study were analyzed univariately.

Result : The results of the univariate research showed that there were 24 (53.3\%) respondents who had an irregular diet, $30(66.7 \%)$ of respondents experienced stress in patients with gastritis at the Simpang IV Sipin Public Health Center Jambi City in 2020.

Conclusion: From the research results, it can be concluded that diet and stress can cause gastritis.

Keyword : stress, diet, gastritis

\section{INTISARI : GAMBARAN POLA MAKAN DAN STRES PADA PENDERITA GASTRITIS DI PUSKESMAS SIMPANG IV SIPIN KOTA JAMBI}

Latar Belakang : Penyakit gastritis yang dikenal dengan penyakit maag merupakan penyakit saluran pencernaan bagian atas yang banyak dikeluhkan di masyarakat. Pada kasus penyakit gastritis di berbagai negara memiliki angka yang cukup tinggi. Gastritis termasuk ke dalam sepuluh penyakit terbanyak pada klien rawat inap rumah sakit di Indonesia dengan jumlah 30.154 kasus. Salah satu faktor penyebab gastritis yaitu pola makan dan stress.

Tujuan : Penelitian ini bertujuan untuk mengetahui gambaran pola makan dan stres dengan gastritis di Puskesmas Simpang IV Sipin Kota Jambi Tahun 2020.

Metode : Penelitian ini merupakan penelitian kuantitatif dengan metode penelitian Deskriptif. Populasi dalam penelitian ini adalah seluruh klien Gastritis yang berkunjung ke Puskesmas Simpang IV Sipin Kota Jambi pada bulan September Tahun 2020 yang berjumlah 45 klien dan pengambilan sampel dilakukan dengan menggunakan teknik total sampling yaitu berjumlah 45 klien. 
Pengumpulan data dilakukan dengan lembar kuesioner dan hasil penelitian ini dianalisis secara univariat.

Hasil : Hasil penelitian univariat menunjukkan bahwa terdapat 24 (53,3\%) responden memiliki pola makan yang tidak teratur, terdapat $30 \quad(66,7 \%)$ responden mengalami stress pada penderita gastritis di Puskesmas Simpang IV Sipin Kota Jambi Tahun 2020.

Kesimpulan : berdasarkan hasil penelitian dapat disimpulkan bahwa pola makan dan stress dapat mengakibatkan kejadian gastritis.

Kata Kunci : Stress, Pola Makan, Gastritis

\section{PENDAHULUAN}

Gastritis merupakan proses inflamasi pada mukosa dan submukosa lambung (Sudoyo, 2014). Gastitis adalah suatu peradangan mukosa lambung yang dapat bersifat akut, kronik, difus, atau lokal yang di sebabkan oleh bakteri atau obatobatan (Price \& Wilson, 2012).

Pada kasus penyakit gastritis di berbagai negara memiliki angka yang cukup tinggi. Berdasarkan tinjauan yang dilakukan oleh World Health Organization (WHO) Tahun 2019 penyakit gastritis di beberapa negara dunia dengan persentase yaitu, 69\% di Afrika, 78\% di Amerika Selatan, dan $51 \%$ di Asia. Di dunia, Kejadian penyakit gastritis sekitar 1,8-2,1 juta penduduk setiap tahunnya, Kejadian penyakit gastritis di Asia Tenggara sekitar 583.635 dari jumlah penduduk setiap tahunnya (Azher, 2020).

Berdasarkan profil kesehatan Indonesia tahun 2018, gastritis termasuk ke dalam sepuluh penyakit terbanyak pada klien rawat inap rumah sakit di Indonesia dengan jumlah 30.154 kasus (Kemenkes RI, 2019).

Gastritis umumnya terjadi akibat asam lambung yang tinggi atau terlalu banyak makan makanan yang bersifat merangsang di antaranya makanan yang pedas dan asam. Kesehatan lambung sanggat erat kaitannya dengan makanan yang dikonsumsi. gastritis merupakan suatu penyakit yang paling sering diakibatkan oleh ketidak teraturan pola makan, misalnya makan terlalu banyak dan cepat atau makan makanan yang terlalu berbumbu. keteraturan makan, frekuensi makan, kebiasaan makan pedas, kebiasaan makan asam, dan frekuensi minuman iritatif merupakan salah satu pemicu terjadinya gastritis (Sukarmin, 2011). Menurut teori kebiasaan makan tidak teratur ini akan membuat lambung sulit untuk beradaptasi. Jika hal itu berlangsung lama, produksi asam lambung akan berlebihan sehingga dapat mengiritasi dinding mukosa pada lambung dan dapat berlanjut menjadi tukak peptik. Hal tersebut dapat menyebabkan rasa perih dan mual. Gejala tersebut bisa naik ke kerongkongan yang menimbulkan rasa panas terbakar (Ganong, 2010)

Selain pola makan, stres juga dapat mengakibatkan kejadian gastritis (Hurst, 2016). Menurut teori stres akan berdampak negatif terhadap sistem pencernaan. Ketika sedang dilanda stres berat, kelenjar liur dapat menghentikan aliran air liur, atau dalam kasus lain, mengalirkannya berlebihan. Lambung meningkatkan asamnya sehingga menimbulkan zat asam, rasa mual dan luka. Banyak juga

orang yang mengeluhkan tentang kejang otot (kram) di daerah perut (Losyk, 2018).

Stres merupakan keadaan yang dialami ketika ada sebuah ketidak sesuaian antara tuntutan-tuntutan yang diterima dan kemampuan untuk 
mengatasinya. Stres terjadi apa bila stresor dirasakan dan dipersepsikan sebagai ancaman sehingga menimbulkan kecemasan yang merupakan awal dari gangguan kesehatan fisik dan psikologis yang berupa perubahan fungsi fisiologis, kognitif, emosi, dan perilaku (Potter dan Perry, 2010). Stres dapat mempengaruhi perubahan fungsi fisiologis sistem tubuh, salah satunya adalah sistem pencernaan dimana stres menurunkan nafsu makan, membuat lambung kosong, meningkatkan asam lambung sehingga menimbulkan rasa nyeri pada lambung (Carolin, 2013).

Bila tubuh mengalami stres, maka akan terjadi perubahan psikologik di dalam tubuh sebagai suatu jawaban atas stres, mayoritas responden yang terdiagnosis gastritis sebelumnya mengalami stres. Stres lebih banyak diakibatkan oleh ketidakmampuan responden menghadapi beban pekerjaan yang berat dan besarnya tekanan hidup yang dialami, sehingga sistem didalam tubuh mengadakan respong melalui sistem syaraf otonom yang selanjutnya akan mempengaruhi fungsi organ-organ tubuh, salah satunya adalah organ pencernaan (Beyors, 2010).

Dari uraian diatas maka peneliti tertarik untuk melakukan penelitian dengan judul "Deteksi Dini Sirkulasi Perifer dengan Palpasi Nadi Dorsalis Pedis dan Pemeriksaan Doppler Pada
Penderita Diabetes Mellitus Tipe II di Puskesmas Kenali Besar Kota Jambi Tahun 2020".

Tujuan penelitian ini untuk mengetahui "Gambaran Pola Makan Dan Stres Pada Penderita Gastritis di Puskesmas Simpang IV Sipin Kota Jambi Tahun 2020".

\section{METODE PENELITIAN}

Penelitian ini merupakan penelitian kuantitatif dengan metode penelitian Deskriptif yang bertujuan untuk mengetahui gambaran pola makan dan stres pada Penderita Gastritis di Puskesmas Simpang IV Sipin Kota Jambi Tahun 2020.

Penelitian ini telah dilakukan pada tanggal $3 \mathrm{~s} / \mathrm{d} 15$ September Tahun 2020 di Puskesmas Simpang IV Sipin Kota Jambi. Instrumen penelitian menggunakan Kuesioner Dan Uji Validitas dan reabilitas.

Populasi dalam penelitian ini adalah seluruh klien Gastritis yang berkunjung ke Puskesmas Simpang IV Sipin Kota Jambi pada bulan September Tahun 2020 yang berjumlah 45 klien dan pengambilan sampel dilakukan dengan menggunakan teknik total sampling yaitu berjumlah 45 klien.

Pengumpulan data dilakukan dengan kuesioner Jacqueline (1995) yang dipakai oleh Maulidia (2016) dan hasil penelitian ini dianalisis secara univariat.

HASIL PENELITIAN DAN PEMBAHASAN

Distribusi Frekuensi Gambaran Pola Makan Dan Stres Pada Penderita Gastritis di Puskesmas Simpang IV Sipin Kota Jambi Tahun 2020

\begin{tabular}{lcc}
\hline \multicolumn{1}{c}{ Pola Makan } & Frekuensi & Persentase (\%) \\
Tidak Teratur & 24 & 53.3 \\
Teratur & 21 & 46.7 \\
\hline \multicolumn{1}{c}{ Stress } & Frekuensi & Persentase (\%) \\
Stress & 30 & 66.7 \\
Tidak Stress & 15 & 33.3 \\
\hline
\end{tabular}


Berdasarkan tabel diatas diketahui bahwa sebagian besar responden memiliki pola makan yang tidak teratur yaitu sebanyak 24 $(53,3 \%)$ responden dan sebagian besar responden mengalami stress yaitu sebanyak $30(66,7 \%)$ responden.

\section{PEMBAHASAN}

Gambaran Pola Makan pada Penderita Gastritis di Puskesmas Simpang IV Sipin Kota Jambi

Berdasarkan hasil penelitian diketahui bahwa sebagian besar responden memiliki pola makan yang tidak teratur yaitu sebanyak 24 $(53,3 \%)$ responden.

Penelitian ini sejalan dengan penelitian yang dilakukan oleh Shalahuddin didapatkan hasil bahwa Responden dengan pola makan yang buruk sebanyak 99 responden (70,7 \%), dan responden dengan pola makan yang baik sebanyak 41 responden (29,3\%) (Shalahuddun, 2018). Penelitian juga dilakukan oleh Arafah dapat dilihat bahwa siswa dengan pola makan yang teratur sebanyak $31(43.1 \%)$, pola makan tidak teratur sebanyak 41 (56,9\%) (Arafah, 2019).

Pola makan merupakan perilaku paling penting yang dapat mempengaruhi keadaan gizi. Hal ini disebabkan karena kuantitas dan kualitas makanan dan minuman yang dikonsumsi akan mempengaruhi tingkat kesehatan individu dan masyarakat (Kemenkes RI, 2014). Sedangkan menurut teori pola makan adalah berbagai informasi yang memberikan gambaran mengenai jumlah dan jenis bahan makanan yang dimakan setiap hari oleh seseorang dan merupakan ciri khas untuk suatu masyarakat tertentu (Almatsier, 2011).

Menuruat Sulistyoningsih (2011) secara umum pola makan memiliki 3 (tiga) komponen yang terdiri dari: jenis, frekuensi, dan jumlah makanan. Pola makan yang terbentuk gambaran sama dengan kebiasaan makan seseorang. Secara umum faktor yang mempengaruhi terbentuknya pola makan adalah faktor ekonomi, sosial budaya, agama, pendidikan, dan lingkungan (Sulistyoningsih, 2011).

Menurut teori kebiasaan makan tidak teratur ini akan membuat lambung sulit untuk beradaptasi. Jika hal itu berlangsung lama, produksi asam lambung akan berlebihan sehingga dapat mengiritasi dinding mukosa pada lambung dan dapat berlanjut menjadi tukak peptik. Hal tersebut dapat menyebabkan rasa perih dan mual. Gejala tersebut bisa naik ke kerongkongan yang menimbulkan rasa panas terbakar (Ganong, 2010).

Penelitian yang dilakukan oleh Diatsa dengan menggunakan uji Spearman menunjukkan bahwa terdapat hubungan yang signifikan antara pola makan dengan kejadian gastritis pada remaja di Pondok AlHikmah, Trayon, Karanggede, Boyolali dengan nilai p-value 0,000. Penelitian juga dilakukan oleh Hamidah didapatkan hasil bahwa ada hubungan antara pola makan dengan kejadian gastritis pada santri tebuireng jombang.sering mengabaikan atau melupakan waktu makan dikarenakan aktivitas padat dengan nilai $p$-value 0,002 .

Menurut teori lain pola makan yang kurang baik akan membuat lambung sulit untuk beradaptasi dalam pengeluaran sekresi asam lambung. Pola makan kurang baik merupakan salah satu penyebab meningkatnya produksi asam lambung dari segi faktor histaminergik dimana hal ini akan mempengaruhi kerja dari sel $G$ untuk produksi hormon gastrin dan juga terjadi defek barier mukosa dan difusi balik ion $\mathrm{H}+$ yang akan merangsanh histamn untuk mempengaruhi kelenjer oksintik 
dalam produksi asam lambung. Jika hal ini berlangsung dalam waktu yang lama, produksi asam lambung akan meningkat secara berlebihan sehingga dapat mengiritasi dinding mukosa lambung menyebabkan gastritis (Sudoyo, 2014).

Berdasarkan hasil penelitian didapatkan hasil bahwa pada jenis makan sebanyak $28 \quad(62,2 \%)$ responden menjawab selalu pada pertanyaan saya memiliki kebiasaan makan makanan pedas, dan sebanyak $32 \quad(71,1 \%)$ responden menjawab sering pada pertanyaan saya memiliki kebiasaan minum teh. Pada frekuensi makan sebanyak 37 $(82,2 \%)$ responden menjawab kadang-kadang pada pertanyaan saya sering mengkonsumsi makanan tambahan (susu, biscuit, roti, buah), dan sebanyak $35(77,8 \%)$ responden menjawab kadang-kadang pada pertanyaan saya mengkonsumsi cemilah sebagai tambahan. Pada jumlah makan sebanyak $36(80,0 \%)$ responden menjawab kadang-kadang pada pertanyaan ketika sarapan saya hanya minum susu, dan sebanyak 24 $(64,4 \%)$ responden menjawab kadang-kadang pada pertanyaan saya makan dalam sehari 3 piring nasi.

Berdasarkan keterangan diatas penelitian berasumsi bahwa ratarata responden yang mempunyai penyakit gastritis adalah orang yang melakukan pola makan tidak teratur. Di Puskesmas Simpang IV Sipin Kota Jambi sebagian besar yang terkena gastritis mengaku bahwa responden suka mengkonsumsi makanan pedas dan suka mengkonsumsi minum minuman bersoda (cola, fanta, sprite dll). Dari hal-hal yang dilakukan responden diatas dapat memicu terjadinya gastritis, maka upaya yang dapat disampaikan yaitu hendaknya memberikan konseling dengan klien yang mengalami gastritis untuk dapat mengurangi pola makan yang tidak baik agar tidak terjadi gastritis.

\section{Gambaran Stres pada Penderita Gastritis di Puskesmas Simpang IV Sipin Kota Jambi Tahun 2020}

Berdasarkan hasil penelitian diketahui bahwa sebagian besar responden mengalami stress yaitu sebanyak $30(66,7 \%)$ responden.

Penelitian ini sejalan dengan penelitian yang dilakukan oleh Widiyanto menunjukan bahwa mayoritas responden dalam kondisi stress yaitu 46 responden $(54,1 \%)$ (Widiyanto, 2014). Penelitian juga dilakukan oleh Mappageran menunjukkan bahwa 30 responden yang memiliki tingkat Stres Normal berjumlah 2 orang $(6,7 \%)$, yang memiliki tingkat stress Ringan berjumlah 9 orang $(30,3 \%)$, yang memiliki tingkat stress Sedang berjumlah 16 orang (53,3\%), yang tingkat stres Berat berjumlah 2 orang $(6,7 \%)$, sedangkan yang memiliki tingkat stress Sangat Berat berjumlah 1 orang (3,3\%) (Mappageran, 2017).

Stres merupakan suatu sistem pertahanan tubuh di mana ada sesuatu yang mengusik integritas diri, sehingga mengganggu ketentraman yang dimaknai sebagai tuntutan yang harus diselesaikan. Selain itu keadaan stress akan muncul apabila ada tuntutan yang luar biasa sehingga mengancam keselamatan atau integritas seseorang (Nasir \& Muhith, 2011).

Menurut teori sterss dibagi menjadi stress ringan, sedang dan berat (Struart, 2013). Menurut teori, stres akan berdampak negatif terhadap sistem pencernaan. Ketika sedang dilanda stres berat, kelenjar liur dapat menghentikan aliran air liur, atau dalam kasus lain, mengalirkannya berlebihan. Lambung meningkatkan asamnya sehingga menimbulkan zat asam, rasa mual dan luka. Banyak juga 
orang yang mengeluhkan tentang kejang otot $(\mathrm{kram})$ di daerah perut (Losyk, 2017).

Stres merupakan keadaan yang dialami ketika ada sebuah ketidak sesuaian antara tuntutan-tuntutan yang diterima dan kemampuan untuk mengatasinya. Stres terjadi apa bila stresor dirasakan dan dipersepsikan sebagai ancaman sehingga menimbulkan kecemasan yang merupakan awal dari gangguan kesehatan fisik dan psikologis yang berupa perubahan fungsi fisiologis, kognitif, emosi, dan perilaku Potter \& Perry, 2010).

Sesuai teori stres dapat mempengaruhi perubahan fungsi fisiologis sistem tubuh, salah satunya adalah sistem pencernaan dimana stres menurunkan nafsu makan, membuat lambung kosong, meningkatkan asam lambung sehingga menimbulkan rasa nyeri pada lambung (Carolin, 2013).

Bila tubuh mengalami stres, maka akan terjadi perubahan psikologik di dalam tubuh sebagai suatu jawaban atas stres, dari hasil penelitian diperoleh mayoritas responden yang terdiagnosis gastritis sebelumnya mengalami stres. Stres lebih banyak diakibatkan oleh ketidakmampuan responden menghadapi beban pekerjaan yang berat dan besarnya tekanan hidup yang dialami, sehingga sistem didalam tubuh mengadakan respong melalui sistem syaraf otonom yang selanjutnya akan mempengaruhi fungsi organ-organ tubuh, salah satunya adalah organ pencernaan. Jika gastritis ini tidak ditangani dengan baik akan menyebabkan terjadinya luka dan perdarahan pada lambung (Beyors, 2010).

Berdasarkan hasil penelitian diketahui bahwa sebanyak $38(84,4 \%)$ responden menjawab kadang-kadang pada pernyataan anda mempunyai banyak masalah, dan sebanyak 33 $(73,3 \%)$ responden menjawab kadang-kadang pada pertanyaan anda merasa sering sakit kepala.

Berdasarkan kesimpulan diatas peneliti berasumsi bahwa dimana salah satu penyebab terjadinya gastritis adalah stres, dikarenakan sistem persyarafan dari otak berhubungan dengan lambung. Jadi tanpa disadari, saat seseorang mengalami stres akan memicu terproduksinya asam lambung secara berlebihan. Asam lambung inilah yang menyebabkan rasa nyeri pada lambung sehingga terjadi gastritis. sehingga disarankan kepada petugas kesehatan dan instansi terkait untuk melakukan promosi kesehatan mengenai penyakit gastritis serta memberikan managemen stres kepada klien yang mengalami gastritis sehingga angka kejadian gastritis dan stress dapat ditekan.

\section{KESIMPULAN}

Diketahui dari 45 responden terdapat $24 \quad(53,3 \%)$ responden memiliki pola makan yang tidak teratur pada penderita gastritis dan terdapat $30 \quad(66,7 \%)$ responden mengalami stress pada penderita gastritis di Puskesmas Simpang IV Sipin Kota Jambi Tahun 2020

\section{DAFTAR PUSTAKA}

Almatsier S., (2011). Prinsip Dasar Ilmu Gizi. Jakarta: Gramedia Pustaka Utama

Arafah (2019). Hubungan Pola Makan Dengan Kejadian Gastritis Pada Siswa Smp Islam Darus Syifa Semper Barat. Jurnal Kesehatan. Vol.3, No.2

Azher et al, (2020). Gastritis. National Center for Biotechnology Information, U.S. National Library of Medicine.

Carolin. (2013). Tingkat Stres Manusia. Jakarta : EGC. 
Diatsa (2016). Hubungan Pola Makan Dengan Kejadian Gastritis Pada Remaja Di Pondok Al-Hikmah, Trayon, Karanggede, Boyolali. Jurnal Kesehatan. Vol.2, No.1.

Ganong, William F. (2010). Buku Ajar Fisiologi Kedokteran. EGC, Jakarta.

Hamidah (2018). Hubungan Pola Makan Dengan Kejadian Gastritis Pada Santri Di Pesantren Tebuireng Jombang. Jurnal Kesehatan. Vol.3, No.1.

Hurst, Marlene. (2016). Keperawatan Medikal Bedah. Jakarta : EGC.

Jacqueline M Atkinson Ph.D. (1995). Kuesioner Stress. Graha Medika : Jakarta.

Kemenkes RI. (2014). Pedoman Gizi Seimbang. Bina Gizi dan KIA. Jakarta.

Kemenkes RI. (2019). Profil Kesehatan Indonesia Tahun 2018. Jakarta : Kemenkes RI.

Losyk (2017). Epidemiology of Peptic Ulcer Disease: Endoscopic Results of the Systematic Investigation of Gastrointestinal Disease in China. Am J 7(4): 42-58.

Maulidia (2016). Hubungan Antra Stres dan Kebiasaan Makan Dengan Terjadinya Kekambuhan Gastritis. Skripsi. Nasir, Abdul dan, Abdul, Muhith. (2011). Dasar-dasar Keperawatan jiwa, Pengantar dan Teori. Jakarta: Salemba Medika.
Potter, Perry. (2010). Fundamental Of Nursing: Consep, Proses and Practice. Edisi 7. Vol. 3. Jakarta : EGC .

Price \& Wilson. (2013). Patofisiologi konsep klinis proses-proses penyakit, edisi ke-6. Jakarta: EGC.

Shalahudin (2018). Hubungan Pola Makan Dengan Gastritis Pada Remaja Di Sekolah Menengah Kejuruan Ybkp3 Garut. Jurnal Kesehatan. Vol.18, No.1.

Stuart G. W Beek dan Sundeen. (2013). Buku Saku Keperawatan Jiwa. (Edisi 5). Jakarta: Penerbit Buku Kedokteran EGC.

Sudoyo. (2014). Buku Ajar Ilmu Penyakit Dalam Jilid II. Edisi ke 6. Jakarta: EGC.

Sukarmin. (2011). Keperawatan pada sistem pencernaan. Pustaka Pelajar, Yogyakarta.

Sulistyoningsih, H. (2011). Gizi untuk Kesehatan Ibu dan Anak Edisi Pertama. Graha IImu. Yogyakarta.

Widiyanto (2014). Hubungan Antara Tingkat Stres Dengan Kejadian Gastritis (Study di Puskesmas Harapan Raya Pekanbaru). Jurnal Kesehatan. Vol.5, No.1 